\title{
Historical, cultural and social perspectives on luxury seafood consumption in China
}

\author{
MICHAEL FABINYI* \\ ARC Centre of Excellence for Coral Reef Studies, James Cook University, Tomnsville, Queensland 4811, Australia
}

Date submitted: 17 August 2011; Date accepted: 8 September 2011; First published online: 24 November 2011

\section{SUMMARY}

Since China is a leading market for a number of types of seafood, and much of this seafood is imported from other countries, Chinese consumption of seafood is an issue of vital importance to many of the world's fisheries. Focusing on luxury seafood, in particular bêche-de-mer, shark fin and live reef food fish, this paper firstly examines the links between Chinese consumption and species population trends in source countries. After a discussion of current efforts at conservation and management of these fisheries, the paper shows how the consumption of luxury seafood in contemporary China is intertwined with broader historical trends, including the expansion of Southern Chinese cuisine; cultural beliefs and traditions, in particular surrounding elements of traditional Chinese medicine; and most importantly, notions of social status and conspicuous consumption linked to the development of the Chinese economy and social stratification. The paper points to the role of the historical, cultural and social processes that underlie Chinese luxury seafood consumption, and to the need for greater levels of action among various actors to address this consumption if sustainability is to be achieved.

Keymords: anthropology, bêche-de-mer, China, live reef food fish, seafood consumption, shark fin

\section{INTRODUCTION}

The rapid economic growth taking place in China over the last several decades has tremendous environmental implications within China and far beyond (Liu \& Raven 2010). One important development that has profound consequences for environments of other regions is higher levels of consumption within China (Putzel et al. 2008; Gerth 2010). With regard to marine environments, rising levels of seafood consumption in China have the capacity to significantly impact on marine resources across the globe.

China is the leading market for a number of types of luxury seafood, such as shark fin (Clarke et al. 2007), bêche-de-mer (Jaquemet \& Conand 1999), and live reef food fish (Sadovy

\footnotetext{
${ }^{*}$ Correspondence: Dr Michael Fabinyi Tel: + 61747816358 e-mail: michael.fabinyi@jcu.edu.au
}

et al. 2003a). Because the source of much of this seafood lies outside of China, in particular in tropical marine regions of the Asia-Pacific, increased demand for these products within China is having a profound effect on the ecosystems and livelihoods of those regions whence the seafood comes (Sadovy et al. 2003a; Uthicke \& Conand 2005). Demand for seafood in China is rising so strongly that combined with a relative lack of attention to luxury seafood consumption issues within China, and poor local capacity for governance in source countries, it overwhelms and undermines local efforts at conservation, leading to significant levels of overfishing and stock depletion (Berkes et al. 2006). The point here is not simplistically to blame China, nor to exoticize or 'Orientalise' (Said 1978) Chinese consumption preferences, but to take stock of the scale and form of Chinese luxury seafood consumption patterns.

The processes of stock decline in source countries and luxury consumption in China are exemplified by three forms of luxury seafood: shark fin, bêche-de-mer and live reef food fish. As marine resources have declined around China, exploitation has progressively shifted to distant geographic locations (Scales et al. 2006; Anderson et al. 2011). Although shark fin is sourced worldwide, bêche-de-mer and live reef food fish are mostly sourced from the Asia-Pacific region. While the potential for full-cycle aquaculture appears to be growing for some species of seafood, wild populations of these forms of seafood are declining, and Chinese consumption patterns are a significant driver of this process (Clarke $e t$ al. 2007; Scales et al. 2007; Anderson et al. 2011).

Details vary for individual species, but all three forms of seafood discussed in this paper are vulnerable to overfishing, show evidence of stock declines, currently have limited potential for widespread full-cycle aquaculture, and, for bêche-de-mer, shark fin and some higher-valued species of live reef food fish, are primarily caught for the Chinese market (see Tables 1-3). Fish caught for the live reef food fish trade (Table 1) are typically long-lived, slow growing and of relatively low abundance (Sadovy et al. 2003a). Napoleon wrasse (Cheilinus undulatus), for example, is a significant component of the live reef food fish trade, and is now considered endangered (Russell 2004). In one location of Malaysia, Napoleon wrasse populations have declined by $98 \%$ and $78 \%$ in catch and relative abundance over a period of eight years, and this is attributed to the trade in live reef food fish (Scales et al. 2007). Sub-adult 'plate-sized' fish are actively targeted, and the high prices for live reef food fish in general gives strong incentives for fishers to overexploit, despite declines in stocks (Fabinyi \& Dalabajan 2011). Sharks 
Table 1 Links between live reef food fish vulnerability to fishing, indicators of overfishing, the potential for aquaculture and Chinese consumption.

\begin{tabular}{|c|c|c|c|}
\hline Vulnerability to fishing & $\begin{array}{c}\text { Indicators of overfishing/population } \\
\text { trends }\end{array}$ & $\begin{array}{c}\text { Potential for full-cycle } \\
\text { aquaculture }\end{array}$ & Links to Chinese consumption \\
\hline $\begin{array}{l}\text { Many groupers and wrasses } \\
\text { long-lived and slow } \\
\text { growing, low abundance; } \\
\text { especially Napoleon wrasse } \\
\text { [Cheilinus undulatus] } \\
\text { (Sadovy et al. } 2003 \mathrm{~b} \text { ); high } \\
\text { vulnerability to fishing } \\
\text { Aggregation sites targeted by } \\
\text { fishers (Sadovy et al. } 2003 a \text { ) }\end{array}$ & $\begin{array}{l}\text { Variable for individual species, but } C \text {. } \\
\text { undulatus listed as endangered in } \\
\text { International Union for the } \\
\text { Conservation of Nature (IUCN) Red } \\
\text { List (Russell 2004). Severe } \\
\text { population declines directly } \\
\text { attributed to the trade (Scales et al. } \\
\text { 2007) } \\
\text { Leopard coral grouper (Plectropomus } \\
\text { leopardus) catch, abundance and } \\
\text { mean size declining in some areas } \\
\text { (Padilla et al. 2003); listed as } \\
\text { near-threatened (Cornish \& Kiwi } \\
\text { 2004) }\end{array}$ & $\begin{array}{l}\text { Many lower-valued species } \\
\text { cultured, but } P \text {. leopardus } \\
\text { cultured minimally; } C \text {. } \\
\text { undulatus not at all }\end{array}$ & $\begin{array}{l}\text { Hong Kong and mainland China } \\
\text { together accounted for c. } 60 \% \\
\text { of the trade in mid-1990s } \\
\text { (Sadovy et al. 2003a). } \\
\text { Preferred 'plate-sized' fish means } \\
\text { sub-adults are actively targeted } \\
\text { High price for live groupers gives } \\
\text { incentives for fishers to } \\
\text { overexploit, despite declines in } \\
\text { stocks (Fabinyi \& Dalabajan } \\
\text { 2011) }\end{array}$ \\
\hline
\end{tabular}

Table 2 Links between shark vulnerability to fishing, indicators of overfishing, the potential for aquaculture and Chinese consumption.

\begin{tabular}{|c|c|c|c|}
\hline Vulnerability to fishing & $\begin{array}{c}\text { Indicators of } \\
\text { overfishing/population trends }\end{array}$ & $\begin{array}{c}\text { Potential for full-cycle } \\
\text { aquaculture }\end{array}$ & Links to Chinese consumption \\
\hline $\begin{array}{l}\text { Chondrichthyans often } \\
\text { characterized by low } \\
\text { growth rates, late sexual } \\
\text { maturity and low } \\
\text { fecundity; means high } \\
\text { vulnerability to fishing } \\
\text { (Myers \& Worm 2005) }\end{array}$ & $\begin{array}{l}\text { Variable for individual species and } \\
\text { many species data deficient } \\
\text { Globally considered to be in } \\
\text { decline: } 32 \% \text { of pelagic sharks } \\
\text { and rays considered 'threatened' } \\
\text { (Camhi et al. } 2009 \text {; see also } \\
\text { Dulvy et al. 2008) }\end{array}$ & None & $\begin{array}{l}\text { Hong Kong handles } 30-50 \% \text { of shark fin } \\
\text { trade; entrepôt for mainland China } \\
\text { (Clarke 2008) } \\
\text { Hong Kong trade data suggests shark fin } \\
\text { trade greater than FAO data suggest } \\
\text { (Clarke } \text { et al. } 2006 \text { ) } \\
\text { Between } 2000 \text { and } 2005 \text { shark fin } \\
\text { accounted for } 40 \% \text { of global market } \\
\text { value of shark trade (Lack \& Sant 2008) }\end{array}$ \\
\hline
\end{tabular}

Table 3 Links between bêche-de-mer vulnerability to fishing, indicators of overfishing, the potential for aquaculture and Chinese consumption.

\begin{tabular}{|c|c|c|c|}
\hline Vulnerability to fishing & $\begin{array}{c}\text { Indicators of } \\
\text { overfishing/population trends }\end{array}$ & $\begin{array}{c}\text { Potential for full-cycle } \\
\text { aquaculture }\end{array}$ & Links to Chinese consumption \\
\hline $\begin{array}{l}\text { Late age at maturity, slow growth, } \\
\text { low rates of recruitment leads to } \\
\text { slow population replenishment } \\
\text { (Anderson } \text { et al. 2011) } \\
\text { Slow movement (often in shallow } \\
\text { waters) gives easy access to } \\
\text { fishers (Anderson } \text { et al. 2011; } \\
\text { Uthicke \& Conand 2005) }\end{array}$ & $\begin{array}{l}\text { 'Overfished in many areas of the } \\
\text { Indo-Pacific' (Ulthicke \& } \\
\text { Conand 2005, p. 9) } \\
\text { 'Populations are in dire straits in } \\
\text { many parts of the world' } \\
\text { (Toral-Granda } \text { et al. } 2008, \text { p. 5) }\end{array}$ & $\begin{array}{l}\text { Practised intensively in } \\
\text { China and other } \\
\text { countries for some } \\
\text { species }\end{array}$ & $\begin{array}{l}\text { Hong Kong the world's largest } \\
\text { entrepôt for bêche-de-mer trade } \\
\text { (Jaquemet \& Conand 1999; } \\
\text { Clarke 2004a) } \\
\text { Global sea cucumber production } \\
\text { 'tightly linked to Asian economy' } \\
\text { (Anderson } \text { et al. } 2011, \text { p. 13) } \\
\text { Increase in demand in mainland } \\
\text { China (Clarke 2004a) }\end{array}$ \\
\hline
\end{tabular}

(Table 2) are also characterized by low growth rates, late sexual maturity and low fecundity, and hence are highly vulnerable to overfishing (Myers \& Worm 2005). Shark populations are considered to be in decline globally (Camhi et al. 2009), and Hong Kong handles between $30-50 \%$ of the shark fin trade (Clarke 2008). Bêche-de-mer (Table 3) are easily caught by fishers and have low rates of recruitment (Anderson et al. 2011). They are overfished in many parts of the world (Toral-
Granda et al. 2008), and consumption is dominated by Hong Kong and mainland China (Clarke et al. 2004a).

Chinese consumption is thus a potential major future driver of stock declines within all of these seafood groups (Sadovy et al. 2003a; Clarke et al. 2007; Anderson et al. 2011).

Gaining a better understanding of different aspects of Chinese seafood consumption will be of considerable importance for efforts to sustain the marine resources that 
feed this market. While detailed, disaggregated and accurate quantitative studies of trends in Chinese seafood consumption remain relatively scant (Clarke 2004a; Clarke et al. 2007; Lam \& Sadovy de Mitcheson 2011), this paper focuses on what historical, cultural and social perspectives can contribute to the issue. The notion that these approaches can contribute to a useful understanding of seafood consumption in China is premised on the assertion that consumption is a multifaceted phenomenon with a range of determinants that cannot be reduced to one disciplinary perspective (Miller 1995; Fine 2002; Wilk 2002). An anthropological perspective on consumption, for example, can highlight the 'inseparability of the material and the social processes involved' (Croll 2006, p. 21). Seafood consumption considered from this perspective is not only about the act of purchasing and consuming a particular product, but about the wider social context of which the act of consumption is a part. Hence, from this perspective, consumption is broadly defined as 'the meaningful use people make of the objects that are associated with them... While anthropologists recognize that some needs have a material basis, they stress the fact that need and demand reflect the ways objects facilitate social relationships and define social identities' (Carrier 1996, p. 128). This emphasis on the social aspects of consumption can be seen most clearly with regard to conspicuous consumption of luxury seafoods.

A range of studies of seafood and wildlife consumption in China informed by conservationist perspectives have identified some of the important themes, such as the associations with traditional Chinese medicine (TCM) and status (Wai Yee 2000; Chan 2001; Zhou \& Jiang 2004; Zhang et al. 2008). Much of the research that has linked consumption of wildlife to particular motivations has been primarily based on large-scale quantitative surveys (but see Anon. 2010). While such surveys have pointed to some social aspects of consumption, they do not provide the whole picture. In addition to such survey-based research, there is also much social science work on seafood consumption, typically not directly concerned with conservation, that has focused on the processes underlying consumption in greater depth. Such an approach helps to contextualize consumption, showing how such behaviour is one element of broader historical, cultural and social patterns.

Based on a comprehensive English language literature review, this paper draws some of the themes of such a range of studies together, with an explicit focus on the implications that they have for conservation. I firstly review the extent of Chinese seafood consumption and efforts at conservation and management, then highlight the role of three themes that are crucial for understanding patterns of contemporary luxury seafood consumption in China: (1) historical patterns of seafood consumption; (2) cultural traditions and beliefs; and most importantly, (3) social processes associated with conspicuous consumption. There is, of course, great diversity within 'Chinese' seafood consumption patterns that are beyond the scope of this paper, namely differences among regions, between urban and rural, and between private or domestic and restaurant or public consumption. The goal here is not to provide an exhaustive review of all the literature pertaining to Chinese seafood consumption, rather to emphasize some of the themes that are of most relevance to those concerned with sustainability, illustrated by the use of particular examples of these themes.

\section{SEAFOOD CONSUMPTION IN CHINA}

Establishing the exact extent and patterns of the consumption of seafood in China is fraught with difficulties. The United Nations Food and Agriculture Organization (FAO) has detailed statistics on fisheries in China, but for production statistics at least: 'there are continued indications that capture fisheries and aquaculture production statistics for China may be too high' (FAO 2008, p. 5; see Watson \& Pauly 2001). The statistics that are available and widely cited for 'food fish supply' (that is, all 'fish and fishery' products [including freshwater fish, and invertebrates] available for consumption), however, show a marked increase, both overall (from 3234 837 tonnes in 1961 to 35364494 tonnes in 2007) and per person (from $4.89 \mathrm{~kg}$ to $26.46 \mathrm{~kg}$ ) (FAOSTAT 2010). A significant proportion of this supply in China likely comes from freshwater aquaculture (FAO 2008, p. 63); in this paper, by contrast, 'seafood' refers to all edible marine products. These figures also do not refer to consumption per se, but to food fish potentially available for human consumption. In addition, with statistics for sharks at least, FAO estimates differ significantly from trade-derived records (Clarke et al. 2006). Given the many loopholes that still exist with regard to monitoring of luxury seafood in China, especially shipments that arrive on vessels via Hong Kong (Sadovy 2011), the exact scale of Chinese luxury seafood consumption remains uncertain.

Other sets of Chinese statistics show the proportion of urban household spending on 'aquatic products' rising from 1\% in 1990 to 4\% in 2007 (China Statistical Yearbook 2008, cited in International Markets Bureau 2010, p. 12). The current state of seafood consumption can also be measured not only in terms of how much seafood is consumed, but also in terms of what types of seafood are being consumed (for example fish at higher trophic levels such as tuna versus anchovy). Defining consumption as net trade flow, excluding farmed fish, China has the highest 'seafood print' (Greenberg 2010). By 2020, China may be consuming $35.9 \mathrm{~kg}$ of food fish per person annually (Delgado et al. 2003, p. 63).

Despite the statistical uncertainty, even a $50 \%$ reduction in reported consumption would exert tremendous market pressures (Clarke 2004a, p. 55). While there are doubts over the data, they give an indication of the likely scale of Chinese seafood consumption. While seafood consumption per person remains lower than in other countries (such as Japan), the sheer population size means that Chinese consumption patterns will inevitably have significant ramifications for world fisheries. 


\section{EFFORTS AT CONSERVATION AND MANAGEMENT}

Many of the countries from which bêche-de-mer, shark fin and live reef food fish are sourced in the Asia-Pacific have various government regulations and non-government organizations (NGOs) that aim to conserve these fisheries (see for bêche-demer and live reef food fish, the SPC Bulletins at http://www. spc.int/coastfish/en/publications/bulletins.html). Despite the proliferation of activities and legislation related to fisheries management and conservation, putting many of these policies and programmes into action usually remains a significant challenge. Frequently, this is because of social issues in source countries such as poverty, overpopulation, the difficulties of establishing alternative livelihoods for fishers, and poor monitoring and enforcement related to corruption and the capacity for governance (Fabinyi \& Dalabajan 2011). Other factors in some source locations include a total lack of controls. In addition to such 'local' problems, one key factor at the broader scale is that the strength of the market demand from China frequently overwhelms any local regulations for sustainability that may exist (Berkes et al. 2006). In the live reef food fish trade in parts of the Philippines, the extremely high price of leopard coral grouper (Plectropomus leopardus) driven by Chinese demand means that the trade is continuing to intensify, despite strong evidence of overfishing, catch declines and the efforts of local governments to regulate the fishery (Fabinyi \& Dalabajan 2011). Because of the power of Chinese market demand to affect marine ecosystems across the Asia-Pacific, global conservation attention has shifted toward examining issues concerning trade and consumption in greater detail.

While there are a range of initiatives underway, integrating sustainability and conservation concerns into Chinese luxury seafood consumption is only at the very early stages. Two key problems that have been identified are the lack of implementation by mainland China of the Convention on International Trade in Endangered Species of Wild Fauna and Flora (CITES) Appendix II regulations, and the lack of adequate monitoring by the Chinese government of luxury seafood imports, particularly those that arrive by vessels through Hong Kong (Sadovy 2011). A recent scoping study into promoting a sustainable fisheries and aquaculture sector in China (both production and consumption) suggested a 'road map' focusing on traceability, quality control, research and development, consolidated standards and certification procedures, and the development of five-year-plans incorporating sustainability principles (Buluswar et al. 2011). An important emerging trend that aims to influence the market end of seafood trade in China is the developing emphasis on market-based approaches to conservation. Recent efforts to reform the live reef food fish trade, for example, focused on the development of international standards and the possibility of implementing a range of market-based measures to improve sustainability (WWF 2011). These efforts have included engagement with a range of governmental and industry stakeholders from China.
CITES and media campaigns are two of the more established and significant conservation interventions in China. Several species of sharks and live reef food fish have been listed on CITES; China and Hong Kong are separate signatories to CITES and have different modes of implementation (Clarke 2004b). For some species, such as Napoleon wrasse (Cheilinus undulatus), CITES listing has resulted in some improvements, such as increased monitoring by Hong Kong customs officials and the establishment of quotas in Indonesia and Malaysia, but many challenges related to implementation of the CITES regulations remain (Sadovy 2010, 2011), often, as described earlier, concerning monitoring and enforcement in source countries in the Asia-Pacific. More broadly, the ways in which international negotiations and politics can hinder the use of CITES as a management tool was highlighted in March 2010, with the rejection of proposals to list several new endangered shark species (Platt 2010).

Many NGOs are campaigning against wildlife consumption, including prominent warnings against shark fin consumption. Large-scale media campaigns by conservation organizations featured Chinese National Basketball Association star Yao Ming in television advertisements screened widely throughout China in 2006 and again in 2009 (WildAid 2010); the message was also publicly advertised at bus stop and video billboards. In 2011, a series of videos articulated reasons for discontinuing the consumption of shark fin soup (Shark Savers 2011). Messages promoted in these media campaigns focus on the role of sharks in the ecosystem and their declining numbers, the cruelty involved in the practice of finning and the presence of mercury in shark fin soup. Several other conservation organizations are also trying to promote the sustainable consumption of live reef food fish and other seafood in Hong Kong, through awareness and educational campaigns and sustainable seafood guides (see for example Bloom Association 2010; WWF 2010).

Such high-profile campaigns may have had some success, or at least raised awareness of the issues involved. A survey conducted by WildAid in the run-up to the Beijing Olympics found that their media campaigns with Yao Ming were having an impact, claiming that of those who had seen the campaign, $83 \%$ had stopped or reduced consumption (Jakarta Globe 2010). A promotional shark fin dinner for Citibank credit card holders in Hong Kong was recently forced to withdraw the promotion (WildSingapore News 2010). In March 2011, a deputy to the National People's Congress, Ding Liguo, proposed legislation to ban the trade of shark fin (China Daily 2011).

While Alibaba, a prominent online Chinese trading company (similar to E-Bay), made much of its decision to stop shark fin trading in 2009 (Ocean Sentry 2009), enforcing this policy has proved difficult, and shark fins are still easily available. While the sustainability issues surrounding shark fin at least seem to be rising in public profile, the same level of attention has yet to be directed at bêche-de-mer and live reef food fish. In contrast to shark fin, sea cucumbers and live reef fish such as groupers may only reach Chinese news sources 
such as China Daily and Xinhua as part of recipes in the food and dining sections.

\section{HISTORICAL, CULTURAL AND SOCIAL ELEMENTS OF CHINESE LUXURY SEAFOOD CONSUMPTION}

\section{Historical elements of luxury seafood consumption}

The consumption of bêche-de-mer and shark fin has long been enjoyed in China. Shark fin apparently became popular as a delicacy during the time of the Song dynasty (960-1279 AD) (Freeman 1977), and it eventually became institutionalized as haute cuisine as a part of banquets prepared for emperors during the Ming dynasty (1368-1644 AD) (Rose 1996, cited in Clarke et al. 2007, p. 307). Similarly, bêche-de-mer consumption has also been recorded from the Ming dynasty (Yifeng 2002; Chen 2003; Akamine 2007).

Recent changes in China's history have had significant effects on modern forms of Chinese seafood consumption. While until the mid-1990s shark fin was consumed mostly in southern provinces and in Hong Kong, Beijing and Shanghai, it is now found in most major cities in China (Clarke et al. 2007; see Li 2007). Since the 1980s and 1990s, the opening up of the economy and the increasing number of wealthier seafood consumers have led to more people consuming luxury seafoods. Chinese economic policy has also recently shifted to encourage domestic consumption as a source of economic growth (Croll 2006; Stein 2009). Aquaculture has also been promoted by the Chinese government as an additional means of seafood production (Hishamunda \& Subasinghe 2003).

Of particular relevance to the spread of this type of seafood consumption is the proliferation and increased popularity of cuisine from coastal areas of Guangdong and Southern Fujian (hereafter referred to as Southern Chinese cuisine) throughout China and beyond (see Simoons 1991; Wu 2002; Klein 2007). Southern Chinese cuisine is closely associated with high species diversity (Anderson \& Anderson 1977) and with seafood consumption (Anderson 1988; Simoons 1991), and this region of China has had a strong role, both historically and in the contemporary world, of seafood trade and consumption (see Yifeng 2002; Anderson 2007; Tagliacozzo \& Chang 2011). Indeed, the current markets for bêche-de-mer, shark fin and live reef food fish throughout the Asia-Pacific were historically developed by highly dispersed and effective trading networks among the international Chinese diaspora, many of whom originated from this region of China (Yifeng 2002; Butcher 2004; Tagliacozzo \& Chang 2011).

Various debates surround why Southern Chinese cuisine came to be so prominent; it seems to date from the Qing period (1644-1912) and may have been due to the role of the region as a global trade centre (Simoons 1991; Klein 2007). During the twentieth century, the emergence of Hong Kong and Guangzhou as centres of economic life in China and their accompanying culinary revitalizations have also been important factors in increasing the visibility and popularity of Southern Chinese cuisine (Cheung 2002; Klein 2007). While 'conspicuous consumption' is seen most notably with regard to highly-priced luxury seafoods (see below), the growing popularity and status of Southern Chinese cuisine (with the emphasis on seafood) mean that the consumption of seafood more generally has become increasingly popular. The changing importance of seafood in national cuisine is of critical importance in understanding why certain luxury seafoods have come to be so commonly consumed in China.

\section{Cultural elements of luxury seafood consumption}

Many of these seafood delicacies were and are consumed partly because of their links with a range of culturally-derived ideas and behaviour. One important cultural perspective of Chinese seafood consumption is linked to TCM. Renewed interest in TCM since the 1980s has been stimulated by the popularization of TCM in the mass media, and the decline of central government provision of healthcare (Gerth 2010). Of particular relevance for the consumption of seafood is the concept of $b u$ foods, which are seen as strengthening or tonic-like (Anderson 1988; Simoons 1991; Newman 2004), and are typically exotic and unusual in appearance (Anderson 1988). As such, bêche-de-mer and shark fin are considered to be bu foods (Anderson 1988). Linked to this exoticism is a preference for rare foods (Klein 2007), as manifested in the high price of Napoleon wrasse (Sadovy \& Vincent 2002). These traits are likely to be related to simple laws of supply and demand (Hu 2005).

Shark fin soup is commonly held to promote general health; similarly, sea cucumber has been included in many historical TCM records since the Ming dynasty (Chen 2003): even the common name for bêche-de-mer in Chinese, hai shen, translates as 'sea ginseng'. Specifically, a medicinal book from 1757 described the medical function of bêche-de-mer as 'to invigorate the kidney, to benefit the essence of life, to strengthen the penis of man and to treat fistula' (Wu 1958 [1757], p. 124, also cited in Yifeng 2002, p. 25).

Connected to the notion of bu foods is the desire for 'wild' foods. Wild foods are considered to be more bu than nonwild foods; as a recent report on the consumption of wildlife in China put it, wild food is considered to be 'unpolluted,' 'precious' and 'special' (Anon. 2010, p. 23). Based on a longterm ethnographic study of nature conservation in China: ' $[t]$ he tonic, curative, or empowering effects believed to come from ingesting the meat, bones, fur, or organs of wild animals represent natural power in its purest form' (Coggins 2003, p. 70-71). According to Roetz, the Confucian doctrine of the subjugation of 'nature' to 'culture', in particular Xunzi's idea of the victory of man over nature, might have 'had a lasting influence on China's cultural history' (Roetz 2010, p. 214). While this view is certainly contested by other streams of philosophical thought in Chinese culture (such as the Daoist appreciation of nature), 'conservationfriendly' perspectives have typically been subordinated to more utilitarian approaches (Harris 2008), as indeed they 
have been in virtually all other cultures and societies through history.

$\mathrm{Bu}$ foods are also related to ideas about sexual potency. While many bu foods may not have the sole or primary purpose of being an aphrodisiac, by virtue of being bu, they are seen to promote sexual potency and virility (Anderson 1988). This means that the consumption of such foods has an explicit gender aspect, something that correlates with surveys that show wildlife consumption is more popular among men than women (Zhang et al. 2008; Anon. 2010). The desire for wild foods also has important implications when it comes to preferences for wild-caught live reef fish, which generally sell for much higher prices than cultured fish (Sadovy \& Vincent 2002).

Apart from the explicit associations with TCM and bu foods, there are other beliefs associated with certain forms of seafood. The emphasis on fresh fish in Southern Chinese cuisine has a long history (Anderson 1988; Simoons 1991), and it is this emphasis that lies behind the development of the live reef fish for food trade. Fish are also associated with prosperity because the character meaning abundance $(y u)$, is a homonym for the character meaning fish $(y u)$. The common New Year's greeting 'nian nian you yu', means 'have abundance every year'. But through the use of the homonym yu, this refers also to fish, and this is emphasized during New Year by giving a whole fish as a gift while saying the phrase. These beliefs and traditions are certainly not shared by the entire contemporary Chinese population, but they provide an indication of why consuming certain forms of seafood originally became popular.

\section{Social elements of luxury seafood consumption}

A large proportion of the seafood consumed in China is undoubtedly related to everyday eating, but much of the luxury seafood that has led to concerns about sustainability is often consumed in the particular social context of banquets. Sharkfin is frequently consumed at banquets, and is a common feature at weddings. The price of many live reef food fish indicates their status as a luxury good; in a Beijing wholesale fish market during March 2010, Napoleon wrasse were selling for $>\mathrm{US} \$ 250 \mathrm{~kg}^{-1}$ and leopard coral grouper for $>\mathrm{US} \$ 100$ $\mathrm{kg}^{-1}$ (personal observation).

One of the key concepts associated with weddings and banquets, indeed with social life generally in China, is that of guanxi (Yang 1994; Kipnis 1997), roughly translated as 'relationship'. Being able to establish and maintain guanxi with different people is seen as an essential part of succeeding in business, or simply participating fully in social life. A major way in which guanxi is enacted is through banquets, which are typically considered in the ethnographic literature as a way of developing social relationships (Bian 2001; see Yang 1994; Kipnis 1997). Ethnographic research on the relationship between guanxi and capitalism has shown how guanxi has flourished in certain contexts and can be linked with higher levels of corruption in the business-government realm (Yang
2002). Certain types of foods, usually seafoods, are expected at banquets, shark fin being the most familiar example.

As is implied from such a description, banquets are very public displays of social status, and there are complex social rules involved with food (Watson 1987). Of key importance here is the work of two social theorists: Veblen, an economist, and Bourdieu, a sociologist. Veblen's (1975 [1899]) notion of 'conspicuous consumption' sought to explain the consumption of luxury goods and display of wealth in late nineteenth century North America. For Veblen, the 'conspicuous' display of material wealth among the new rich 'leisure class' was in order to gain status and prestige and to mark themselves out from other social classes. Bourdieu (1984) analysed how taste and preferences in consumption were deeply linked with class identity and class relations. Bourdieu's analysis of how richer elites use social, cultural and symbolic capital to distinguish themselves from other classes has been immensely influential across the social sciences, and much of the anthropological discussions of consumption in contemporary China (especially that of luxury goods) have drawn on his and Veblen's ideas (see Buckley 1999; Wang 2000; Wu \& Cheung 2002; Smart 2004; Goodman 2008). Consumption of various goods may serve to solidify social status or function as a way in which people from lower classes can attempt to identify with more prestigious sectors of society and attain upward social mobility (Wang 2000; Harrell 2001).

It is in this context of conspicuous consumption and social networking that the consumption of high-value seafood takes place. This is part of a long historical tradition in China: when Marco Polo visited China during the Song dynasty, for example, he noted a high level of differentiation between the food eaten by the rich and the poor (Goody 1982; see also Chang 1977). In the south of China, shark fins have long been considered a high-status food (Anderson \& Anderson 1977). However, modern forms of conspicuous consumption have been greatly exacerbated by the expansion of the economy since the 1980s and 1990s, and the widening gaps between richer and poorer consumers (Goodman 2008; Gerth 2010). As such, modern consumption of luxury goods such as seafood should be seen not so much as a particularly 'Chinese' form of consumption, but rather as 'expressions of economic power in an era of rapid economic growth' (Cartier 2008, p. 189). As Wilk (2002, p. 7) observed for social perspectives on consumption in modern societies more generally, '[in] any society where there is social differentiation, consumption will have an important role in asserting or challenging rank and status'.

In China, luxury seafood is consumed by richer members of society at banquets, where consumption serves as a realm in which 'claims to social esteem [are] enacted' (Hanser 2010 , p. 328), and the practice of guanxi deployed (Yang 2002). These social performances of consumption are not available to everyone within Chinese society; indeed, the luxury consumption patterns of 'the new rich' are frequently deeply resented in what was very recently a nominally socialist country, with strong Confucian ideals of not flaunting 
wealth (Gerth 2010). The new rich in China are frequently perceived to have acquired their wealth dishonestly or through corruption (Croll 2006; Gerth 2010).

\section{DISCUSSION}

This paper has reviewed how luxury seafood consumption in China is closely linked to the decline of three particular marine groups in many source locations of the Asia-Pacific; Chinese consumption patterns have evidently had significant effects on seafood source populations (Tables 1-3). In many cases, attempts to sustain marine resources in source countries have been undermined by strong market demand from China (Berkes et al 2006; Scales et al. 2006; Anderson et al. 2011). Given that management in source countries has frequently been ineffective, attention has more recently shifted to Chinese consumption patterns.

Consuming luxury seafood in China has long been historically prominent, has intensified since the Qing dynasty, and has more recently taken on a new dimension as a part of a broader social process concerned with status, conspicuous consumption and distinction. By reviewing this literature, this paper aimed firstly to draw these themes together for those interested in the contexts of luxury seafood consumption in China, and secondly, to highlight how such consumption is one element within processes operating at much wider social contexts. Greater understanding of the role of the historical, cultural and social processes that underlie this consumption is required, and greater levels of action among various actors to address this consumption are needed if resources are to be sustained.

Different perspectives on consumption have different sets of implications for environmental policy, and any comprehensive successful strategy for addressing luxury seafood consumption in China will likely need to take a 'pragmatic pluralist approach' (Wilk 2002, p. 9). Such a strategy would include engagement with a range of actors, such as the government, NGOs, private traders and the general population. As indicated earlier, ongoing efforts to reform elements of Chinese luxury seafood consumption include the development of international standards for the live reef fish for food trade, the use of CITES to control the trade of protected species, meetings with industry players and the development of a road map engaging the Chinese government on sustainability issues (Buluswar et al. 2011). Better quality and more transparent data collection on the luxury seafood trade is required by the Chinese government, especially with regard to re-exports originating from Hong Kong, which remains a major redistribution point of luxury seafood; this would at least allow stakeholders to talk about the issue with some degree of clarity and authority. Continuing efforts are required in source countries, such as the Philippines and Indonesia, to address the overfishing of bêche-de-mer, sharks and live reef fish. However, given the significant problems related to livelihood, poverty and governance in many source countries, it is unlikely that these trades will be sustained without action from the Chinese consumption end of the commodity chain.

While there are many drivers of Chinese luxury seafood consumption, this paper has emphasized the recent emergence of the role of social competition and status attainment. The important role of banquets in luxury seafood consumption points to the potential benefits of continuing to engage the restaurant sector as a part of consumer-oriented campaigns (for example see To 2011). Viewing consumption from this social perspective also suggests that current consumeroriented media and awareness campaigns that associate members of high-status groups with the rejection of or sustainable alternatives to shark fin are appropriate methods of achieving conservation goals (Wilk 2002). By reducing the social attraction of particular products through their disassociation with high-status members of society, such campaigns may end up doing more in the long term to reduce consumption than regulatory approaches alone. One advantage of a consumer-oriented approach is that it appeals directly to social values and avoids the frequently unpredictable interactions between and within governments.

However, the difficulties with such consumer-oriented awareness campaigns should not be underestimated (Jacquet \& Pauly 2007). Any campaign that attempts to change the values and consumption choices of millions of consumers across China will likely need to be a long-term project (Buluswar et al. 2011). While there is much well-publicized awareness and concern in China over issues concerning food quality and food safety, and there is increasing interest in practices such as organic farming, large-scale consumer interest in the sustainability of food products has yet to be demonstrated. Indeed, the difficulties of implementing consumer awareness campaigns in China have led to a conclusion that in the near to medium term, such campaigns are unlikely to have much impact, and that other measures (such as improved traceability and government standards) will be more effective and should be prioritized instead (Buluswar et al. 2011).

Despite these likely barriers to change, a social perspective on consumption that emphasizes conspicuous consumption also suggests that broader initiatives that 'reduce social inequality and therefore social competition' (Wilk 2002, p. 8) will be most effective in the long term. This points to the role of other social, economic and political institutions and organizations that may be able to contribute to reducing the consumption of high-value seafoods. Indeed, the Chinese government has recently recognized unequal income distribution within the country as a problem that needs to be addressed (Xinhua 2011), and has ostensibly made a public effort to stamp out corruption (Croll 2006). In addition to specific policy actions relating to luxury seafood consumption, broader efforts to reduce inequality and corruption, which do not focus on the resource itself, may prove just as relevant over the long term.

Indeed, viewing seafood consumption from diverse historical, cultural and social perspectives indicates how such behaviour is embedded within a vast range of values, goals 
and ideas. This shifts the perspective from the material act of consumption in itself to being just one element in a more fundamental process of the pursuit of personal and social well-being (Croll 2006; Wilk 2002). The most effective ways in which such patterns of consumption may be influenced may not be through a narrow focus on consumption itself, but through the development and change of the broader societal values and beliefs that frame such consumption practices.

\section{ACKNOWLEDGEMENTS}

Thanks to Sarinda Singh for comments on an earlier draft of the manuscript, the anonymous reviewers, and Andrew Chin who first suggested the review.

\section{References}

Akamine, J. (2007) Namako and iriko: historical overview on holothuria (sea cucumber) exploitation, utilization, and trade in Japan. In: Food and Foodways in Asia: Resource, Tradition and Cooking, ed. S.C.H. Cheung \& T. Chee-Beng, pp. 23-36. London, UK and New York, NY, USA: Routledge.

Anderson, E.N. (1988) The Food of China. London, UK and New Haven, CT, USA: Yale University Press.

Anderson, E.N. (2007) Floating World Lost: A Hong Kong Fishing Community. New Orleans, USA: University Press of the South.

Anderson, E.N. \& Anderson, M.L. (1977) Modern China: South. In: Food in Chinese Culture, ed. K.C. Chang, pp. 317-382. New Haven, CT, USA and London, UK: Yale University Press.

Anderson, S.C., Flemming, J.M., Watson, R. \& Lotze, H.K. (2011) Serial exploitation of global sea cucumber fisheries. Fish and Fisheries 12(3): 317-339.

Anon. (2010) Understanding the motivations: the first step toward influencing China's unsustainable wildlife consumption. Report. TRAFFIC East Asia, Hong Kong.

Berkes, F., Hughes, T.P., Steneck, R.S., Wilson, J.A., Bellwood, D.R., Crona, B., Folke, C., Gunderson, L.H., Leslie, H.M., Norberg, J., Nyström, M., Olsson, P., Österblom, H., Scheffer, M. \& Worm, B. (2006) Globalization, roving bandits, and marine resources. Science 311: 1557-1558.

Bian, Y. (2001) Guanxi capital and social eating in Chinese cities: theoretical models and empirical analyses. In: Social Capital: Theory and Research, ed. N. Lin, K. Cook \& R.S. Burt, pp. 275295. New York, NY, USA: Aldine de Gruyter.

Bloom Association (2010) Education and awareness. France [www document]. URL http://www.bloomassociation.org/ bloom/abysses-awareness-en.php

Bourdieu, P. (1984) Distinction. London, UK: Routledge and Kegan Paul.

Buckley, C. (1999) How a revolution becomes a dinner party: stratification, mobility and the new rich in China. In: Culture and Privilege in Capitalist Asia, ed. M. Pinches, pp. 208-229. London, UK: Routledge.

Buluswar, S., Cook, S., Stephenson, J., Au, B., Mylavarapu, S. \& Ahmad, N. (2011) Sustainable fisheries and aquaculture in China: scoping opportunities for engagement. Report prepared for the David and Lucile Packard Foundation, Los Altos, CA, USA, by Dalberg Global Development Advisors, Seaweb and Sustainable
Fisheries Partnership, in association with M. Siggs of Seaweb, K Short and W. Songlin of WWF and D. Jones of Sustainable Fisheries Partnership.

Butcher, J.G. (2004) The Closing of the Frontier: A History of the Marine Fisheries of Southeast Asia C. 1850-2000. Singapore: Institute of Southeast Asian Studies.

Camhi, M.D., Valenti, S.V., Fordham, S.V., Fowler, S.L. \& C. Gibson. (2009) The Conservation Status of Pelagic Sharks and Rays. Report. IUCN Shark Specialist Group Pelagic Shark Red List Workshop, IUCN Species Survival Commission Shark Specialist Group, Newbury, UK.

Carrier, J.G. (1996) Consumption. In: Encylopedia of Social and Cultural Anthropology, ed. A. Barnard \& J. Spencer, pp. 128-129. London, UK and New York, NY, USA: Routledge.

Cartier, C. (2008) The Shanghai-Hong Kong connection: fine jewelry consumption and the demand for diamonds. In: The New Rich in China, ed. D. Goodman, pp. 187-200. London, UK and New York, NY, USA: Routledge.

Chan, N.W.W. (2001) An integrated attitude survey on live reef food fish consumption in Hong Kong. SPC Live Reef Fish Information Bulletin 8: 9-12.

Chang, K.C. (1977) Introduction. In: Food in Chinese Culture, ed. K.C. Chang, pp. 1-21. New Haven, CT, USA and London, UK: Yale University Press.

Chen, J. (2003) Overview of sea cucumber farming and sea ranching practices in China. SPC Beche-de-mer Information Bulletin 18: 1823.

Cheung, S.C.H. (2002) Food and cuisine in a changing society: Hong Kong. In: The Globalization of Chinese Food, ed. D.Y.H. Wu \& S.C.H. Cheung, pp. 100-112. London, UK and New York, NY, USA: Routledge.

China Daily (2011) Chinese lawmaker urges ban on shark fin trading [www document]. URL http://www.chinadaily.com.cn/china/ 2011npc/2011-03/09/content_12143344.htm

Clarke, S.C. (2004a) Understanding pressures on fishery resources through trade statistics: a pilot study of four products in the Chinese dried seafood market. Fish and Fisheries 5: 53-74.

Clarke, S.C. (2004b) Shark product trade in Hong Kong and Mainland China and implementation of the CITES shark listings. Report. TRAFFIC East Asia, Hong Kong [www document]. URL http://www.traffic.org/fish/

Clarke, S.C. (2008) Use of shark fin trade data to estimate historic total shark removals in the Atlantic Ocean. Aquatic Living Resources 21: 373-381.

Clarke, S.C., McAllister, M.K., Milner-Gulland, E.J., Kirkwood, G.P., Michielsens, C.G.J., Agnew, D.J., Pikitch, E.K., Nakano, H. \& Shivji, M.S. (2006) Global estimates of shark catches using trade records from commercial markets. Ecology Letters 9: 11151126.

Clarke, S.C., Milner-Gulland, E.J., Bjørndal, T. (2007) Social, economic, and regulatory drivers of the shark fin trade. Marine Resource Economics 22: 305-327.

Coggins, C. (2003) The Tiger and the Pangolin: Nature, Culture, and Conservation in China. Honolulu, HI, USA: University of Hawai'i Press.

Cornish, A. \& Kiwi, L.K. (2004) Plectropomus leopardus. In: IUCN 2010. IUCN Red List of Threatened Species [www document]. URL http://www.iucnredlist.org/apps/redlist/details/44684/0

Croll, E. (2006) China's Nem Consumers: Social Development and Domestic Demand. London, UK and New York, NY, USA: Routledge. 
Delgado, C.L., Wada, N., Rosegrant, M.W., Meijer, S. \& Ahmed, M. (2003) Fish to 2020: supply and demand in changing global markets. Worldfish Center Technical Report 62, International Food Policy Research Institute and Worldfish Center: 226 pp. [www document]. URL http://www.ifpri.org/ sites/default/files/pubs/pubs/books/fish2020/oc44front.pdf

Dulvy, N.K., Baum, J.K., Clarke, S., Compagno, L.J.V., Cortés, E., Domingo, A., Fordham, S., Fowler, S., Francis, M.P., Gibson, C., Martínez, J., Musick, J.A., Soldo, A., Stevens, J.D. \& Valenti, S. (2008) You can swim but you can't hide: the global status and conservation of oceanic pelagic sharks and rays. Aquatic Conservation: Marine and Freshmater Systems 18: 459-482.

Fabinyi, M. \& Dalabajan, D. (2011) Policy and practice in the live reef fish for food trade: a case study from Palawan, Philippines. Marine Policy 35: 371-378.

FAO (2008) The state of world fisheries and aquaculture (SOFIA). In: FAO Fisheries and Aquaculture Department [www document]. URL http://www.fao.org/fishery/sofia/en

FAOSTAT (2010) Food supply: livestock and fish primary equivalent [www document]. URL http://faostat.fao.org/site/ 610/DesktopDefault.aspx?PageID $=610$

Fine, B. (2002) The World of Consumption: The Material and Cultural Revisited. Second edition. London, UK and New York, NY, USA: Routledge.

Freeman, M. (1977) Sung. In: Food in Chinese Culture, ed. K.C. Chang, pp. 141-192. New Haven, CT, USA and London, UK: Yale University Press.

Gerth, K. (2010) As China Goes, So Goes the World: How Chinese Consumers are Transforming Everything. New York, NY, USA: Hill and Wang.

Goodman, D., ed. (2008) The New Rich in China. London, UK and New York, NY, USA: Routledge.

Goody, J. (1982) Cooking, Cuisine and Class: A Study in Comparative Sociology. Cambridge, UK: Cambridge University Press.

Greenberg, P. (2010) Seafood crisis. National Geographic December 2010 [www document]. URL http://ngm.nationalgeographic. com/2010/10/seafood-crisis/greenberg-text

Hanser, A. (2010) Uncertainty and the problem of value: consumers, culture and inequality in urban China. Fournal of Consumer Culture 10: $307-332$.

Harrell, S. (2001) The anthropology of reform and the reform of anthropology: anthropological narratives of recovery and progress in China. Annual Reviem of Anthropology 30: 139-161.

Harris, R.B. (2008) Wildlife Conservation in China: Preserving the Habitat of China's Wild West. New York, NY, USA: East Gate Press.

Hishamunda, N. \& Subasinghe, R. (2003) Aquaculture Development in China: the Role of Public Sector Policies. FAO Fisheries Technical Paper. No. 427. Rome, Italy: FAO: 64 pp.

Hu, S. (2005) Food Plants of China. Hong Kong: The Chinese University Press.

International Markets Bureau (2010) The urban Chinese consumer: Behaviour, attitudes and perceptions toward food products. Market Analysis Report. Agriculture and Agri-Food Canada, International Markets Bureau, Ottawa, Canada: 27 pp.

Jacquet, J. \& Pauly, D. (2007) The rise of seafood awareness campaigns in an era of collapsing fisheries. Marine Policy 31: 308 313.

Jakarta Globe (2010) Teeth out in shark-fin fight [www document]. URL http://www.thejakartaglobe.com/lifeandtimes/teeth-outin-shark-fin-fight/397316
Jaquemet, S. \& Conand, C. (1999) The bêche-de-mer trade in $1995 / 1996$ and an assessment of exchanges between the main world markets. SPC Beche-de-mer Information Bulletin 12: 11-14.

Kipnis, A.B. (1997) Producing Guanxi: Sentiment, Self and Subculture in a North China Village. Durham, NC, USA and London, UK: Duke University Press.

Klein, J. (2007) Redefining Cantonese cuisine in post-Mao Guangzhou. Bulletin of SOAS 70: 511-537.

Lack, M. \& Sant, G. (2008) Illegal, unreported and unregulated shark catch: a review of current knowledge and action. Report. Department of Environment, Water, Heritage and the Arts and TRAFFIC International, Canberra, Australia [www document]. URL http://www.traffic.org/fish/

Lam, V.Y.Y. \& Sadovy de Mitcheson, Y. (2011) The sharks of South East Asia: unknown, unmonitored and unmanaged. Fish and Fisheries 12(1): 51-74.

Li, P. (2007) Enforcing wildlife protection in China: the legislative and political solutions. China Information 21: 71-107.

Liu, J. \& Raven, P.H. (2010) China's environmental challenges and implications for the world. Critical Reviems in Environmental Science and Technology 40: 823-851.

Miller, D. (1995) Consumption and commodities. Annual Reviem of Anthropology 24: 141-161.

Myers, R.A. \& Worm, B. (2005) Extinction, survival, or recovery of large predatory fishes. Proceedings of the Royal Society B $\mathbf{3 6 0}$ : 13-20.

Newman, J.M. (2004) Food Culture in China. Westport, CT, USA: Greenwood Press.

Ocean Sentry (2009) Alibaba.com. Selling sharks fin 5000 kilos a week [www document]. URL http://www.oceansentry.org/langen/menu-news/menu-sharks/1473-alibaba-com-selling-sharksfin-5000-kilos-a-week.html

Platt, J. (2010) Shark fin soup: CITES fails to protect five species of sharks from overfishing and finning. Scientific American March 25 [www document]. URL http://www.scientificamerican. com/blog/post.cfm?id=shark-fin-soup-cites-fails-to-prote2010-03-24

Putzel, L., Padoch, C. \& Pinedo-Vasquez, M. (2008) The Chinese timber trade and the logging of Peruvian Amazonia. Conservation Biology 22: 1659-1661.

Roetz, H. (2010) On nature and culture in Zhou China. In: Concepts of Nature: A Chinese-European Cross-Cultural Perspective, ed. H. Vogel \& G. Dux, pp. 198-219. Leiden, the Netherlands: Koninklijke Brill NV.

Rose, D.A. (1996) An overview of world trade in sharks and other cartilaginous fishes. Report. TRAFFIC International, Cambridge, UK [www document]. URL http://www.traffic.org/fish/

Russell, B. (2004) Cheilinus undulatus. In: IUCN 2010. IUCN Red List of Threatened Species. Version 2010.4 [www document]. URL http://www.iucnredlist.org/apps/redlist/details/4592/0

Sadovy, Y.J. (2010) Humphead wrasse and illegal, unreported and unregulated fishing. SPC Live Reef Fish Information Bulletin 19: $19-21$.

Sadovy, Y.J. (2011) Regional cooperation on policy, enforcement and IUU fishing: the CITES example. Workshop on MarketBased Improvements in Live Reef Fish Food Trade, Bali, 1-3 March [www document]. URL http://wwf.panda. org/what_we_do/where_we_work/coraltriangle/events/live_ reef_food_fish_trade_workshop/speeches_and_presentations/

Sadovy, Y.J. \& Vincent, A.C.J. (2002) Ecological issues and the trades in live reef fishes. In: Coral Reef Fishes: Dynamics and Diversity in 
a Complex Ecosystem, ed. P.F. Sale, pp. 391-420. San Diego, CA, USA: Academic Press.

Sadovy, Y.J., Donaldson, T.J., Graham, T.R., McGilvray, F., Muldoon, G.J., Phillips, M.J., Rimmer, M.A., Smith, A. \& Yeeting, B. (2003a) The Live Reef Food Fish Trade: While Stocks Last. Manila, the Philippines: Asian Development Bank.

Sadovy, Y.J., Kulbicki, M., Labrosse, P., Letourneur, Y., Lokani, P. \& Donaldson, T.J. (2003b) The humphead wrasse, Cheilinus undulatus: synopsis of a threatened and poorly known giant coral reef fish. Reviems in Fish Biology and Fisheries 13: 327364.

Said, E. (1978) Orientalism. New York, NY, USA: Pantheon Books.

Scales, H., Balmford, A., Liu, M., Sadovy, Y. \& Manica, A. (2006) Keeping bandits at bay? Science 313: 612-613.

Scales, H., Balmford, A. \& Manica, A. (2007) Impacts of the live reef fish trade on populations of coral reef fish off northern Borneo. Proceedings of the Royal Society B 274: 989-994.

Shark Savers (2011) Shark fin soup campaign [www document]. URL http://www.sharksavers.org/en/sharkfinsoup.html

Simoons, F.J. (1991) Food in China: A Cultural and Historical Inquiry. Boston, CT, USA: CRC.

Smart, J. (2004) Globalisation and modernity. A case study of cognac consumption in Hong Kong. Anthropologica 46: 219-229.

Stein, K. (2009) Understanding consumption and environmental change: a cross-national comparison of consumer patterns. Human Ecology Reviem 16: 41-49.

Tagliacozzo, E. \& Chang, W. (2011) Chinese Circulations: Capital, Commodities and Networks in Southeast Asia. Durham, NC, USA and London, UK: Duke University Press.

To, A. (2011) Linking market trade and marine conservation: Hong Kong's case study. Workshop on Market-Based Improvements in Live Reef Fish Food Trade, Bali, 1-3 March [www document]. URL http://wwf.panda.org/what_we_do/where_we_work/ coraltriangle/events/live_reef_food_fish_trade_workshop/ speeches_and_presentations/

Toral-Granda, T., Lovatelli, A. \& Vasconcellos, M., eds (2008) Sea Cucumbers: A Global Reviem on Fishery and Trade. FAO Fisheries Technical Paper No. 516. Rome, Italy: FAO: 319 pp.

Uthicke, S. \& Conand, C. (2005) Local examples of beche-de-mer overfishing: an initial summary and request for information. SPC Beche-de-mer Information Bulletin 21: 9-14.

Veblen, T. (1975) [1899]) The Theory of the Leisure Class. New York, NY, USA: A.M. Kelley.

Wai Yee, N. (2000) Attitudes to sharks and shark fin consumption in East Asia. Shark Conference 2000 Online Documents [www document]. URL http://www.pacfish.org/ sharkcon/documents/ng.html

Wang, G. (2000) Cultivating friendship through bowling in Shenzhen. In: The Consumer Revolution in Urban China, ed. D. Davis, pp. 250-267. Berkeley, CA, USA: University of California Press.
Watson, J.L. (1987) From the common pot: feasting with equals in Chinese society. Anthropos 82: 389-401.

Watson, R. \& Pauly, D. (2001) Systematic distortion in world fisheries catch trends. Nature 414: 534-536.

WildAid (2010) Yao Ming swears off shark's fin soup [www document]. URL http://www.wildaid.org/news/yaoming-swears-sharks-fin-soup

WildSingapore News (2010) A Hong Kong shark fin promotion backfires: no complaints for similar promotion in Singapore [www document]. URL http://wildsingaporenews. blogspot.com/2010/07/hong-kong-shark-fin-promotionbackfires.html

Wilk, R. (2002) Consumption, human needs, and global environmental change. Global Environmental Change: 12: 5-13.

Wu, D.Y.H. (2002) Cantonese cuisine (Yue-cai) in Taiwan and Taiwanese cuisine (Tai-cai) in Hong Kong. In: The Globalization of Chinese Food, ed. D.Y.H. Wu \& S.C.H. Cheung, pp. 86-99. London, UK and New York, NY, USA: Routledge.

Wu, D.Y.H. \& Cheung, S.C.H. (2002) Introduction: the globalization of Chinese food and cuisine: markers and breakers of cultural barriers. In: The Globalization of Chinese Food, ed. D.Y.H. Wu \& S.C.H. Cheung, pp. 1-18. London, UK and New York, NY, USA: Routledge.

Wu, Y. (1958 [1757]) Bencao Congxin [Renewal of material medicine]. Shanghai, China:Shanghai Kexue Jishu Chubanshe.

WWF (2010) Building a sustainable live reef food fish trade [www document]. URL http://wwf.panda.org/what_we_do/where_ we_work/coraltriangle/solutions/live_reef_fish_trade/

WWF (2011) Live reef food fish trade workshop [www document]. URL http://wwf.panda.org/what_we_do/where_ we_work/coraltriangle/events/live_reef_food_fish_trade_ workshop/

Xinhua (2011) Premier Wen says China to ensure fair income distribution [www document]. URL http://news.xinhuanet.com/ english2010/china/2011-02/27/c_13752184.htm

Yang, M. (1994) Gifts, Favors and Banquets: The Art of Social Relationships in China. Ithaca, NY, USA and London, UK: Cornell University Press.

Yang, M. (2002) The resilience of guanxi and its new deployments: a critique of some new guanxi scholarship. The China Quarterly 170: 459-476.

Yifeng, D. (2002) Food culture and overseas trade: the trepang trade between China and Southeast Asia during the Qing dynasty. In: The Globalization of Chinese Food, ed. D.Y.H. Wu \& S.C.H. Cheung, pp. 21-42. London, UK and New York, NY, USA: Routledge.

Zhou, Z. \& Jiang, Z. (2004) International trade status and crisis for snake species in China. Conservation Biology 18: 1386-1394.

Zhang, L., Hua, N. \& Sun, S. (2008) Wildlife trade, consumption and conservation awareness in southwest China. Biodiversity and Conservation 17: 1493-1516. 